\title{
Distribution, abundance, and survivorship of young-of-the-year in a commercially exploited population of horseshoe crabs Limulus polyphemus
}

\author{
Mark L. Botton ${ }^{1, *}$, Robert E. Loveland ${ }^{2}$, Athena Tiwari ${ }^{3}$ \\ ${ }^{1}$ Department of Natural Sciences, Fordham College at Lincoln Center, 113 West 60th Street, New York, New York 10023, USA \\ ${ }^{2}$ Department of Ecology, Evolution, and Natural Resources, Rutgers University, Cook College, New Brunswick, New Jersey 08901, USA \\ ${ }^{3}$ Department of Biological Sciences, Fordham College at Rose Hill, Larkin Hall, 441 East Fordham Road, Bronx, New York 10458, USA
}

\begin{abstract}
Horseshoe crab Limulus polyphemus eggs are laid on sandy estuarine beaches, and subsequently develop into first instar (trilobite) larvae that emerge into the plankton before settlement. To obtain estimates of early survival, we collected data on the densities of trilobite larvae within intertidal sediments on a beach in Delaware Bay, New Jersey, and the densities of post-settlement juveniles, through the first 4 instar stages, on the adjacent tidal flats. Over the course of the spawning season in 1999, there were some 761000 live trilobites produced within a $1 \times 3 \mathrm{~m}$ band of intertidal beach. Losses (mortality + emigration) were highest during the brief planktonic phase or shortly after settlement to the benthos; we estimated that about $97.5 \%$ of the live trilobites on the beaches were lost during their transition to epibenthic trilobites on the intertidal flats. Newly settled horseshoe crab juveniles were not dependent on a specific sediment type, but tended to be more abundant close to shore. After settlement, there was about a log-fold decrease in juvenile density with each molt from the second through the fourth instar. Overall, only about 3 larvae per 100000 remained as fourth instar juveniles on the tidal flats at the end of their first summer. Our ability to extrapolate future adult year-class strengths based on young-of-the-year densities is limited, because 9 to $10 \mathrm{yr}$ are required for horseshoe crabs to reach sexual maturity.
\end{abstract}

KEY WORDS: Horseshoe crab · Limulus polyphemus · Recruitment · Fisheries · Delaware Bay

\section{INTRODUCTION}

The American horseshoe crab Limulus polyphemus L. is distributed from northern Maine to the Yucatan peninsula, from about 42 to $19^{\circ} \mathrm{N}$ (Shuster 1982). They are found within estuaries and on the inshore continental shelf near the mouths of estuaries, typically in waters $<30$ m deep (Shuster 1979, Botton \& Ropes 1987a). The species is most abundant in the midAtlantic, especially in the Delaware Bay region, where it provides the basis of important commercial fisheries (Botton \& Ropes 1987b, Berkson \& Shuster 1999). Substantial numbers of horseshoe crabs, on the order of 2.5 million $\mathrm{yr}^{-1}$, are taken for use as bait in fisheries for whelks and eels (ASMFC 1998). Another important commercial use has developed based on the production of Limulus amoebocyte lysate (LAL), which is used to screen pharmaceutical products for the presence of gram-negative bacterial endotoxin (Novitsky 1984). The bleeding of some 200000 to 250000 horseshoe crabs annually is required for LAL production (ASMFC 1998). Until last year, the US Food and Drug Administration (USFDA) mandated the return of all bled crabs to the water within $72 \mathrm{~h}$, but LAL producers now have the option of selling bled crabs to bait dealers. However, the majority of the bled crabs are returned to the water alive, where they experience 4 to $15 \%$ mortality as a result of bleeding and handling (ASMFC 1998).

The magnitude of Delaware Bay's horseshoe crab population impacts wider ecological consequences that, 
in turn, have economic ramifications. Ecotourism based on the viewing of the horseshoe crab and shorebird migrations brings an annual US $\$ 2.6$ to 3.9 million into the economy of Cape May and Cumberland Counties, New Jersey (Manion et al. 2000). For about 3 wk starting in early May, Delaware Bay is a major stopover for some 425000 to 1000000 shorebirds, engaged in their yearly migration to the Arctic breeding grounds (Clark et al. 1993). Most shorebirds that arrive at Delaware Bay have traveled 2800 to $3200 \mathrm{~km}$ from South America, and will travel another $4000 \mathrm{~km}$ to the Arctic (Castro \& Myers 1993, Clark et al. 1993). Horseshoe crab eggs form the major component of the birds' diet during their stopover in Delaware Bay (Tsipoura \& Burger 1999). A high density of eggs in the upper $5 \mathrm{~cm}$ of sediment appears necessary to support the shorebird population, because eggs at greater depths are largely beyond the reach of these shorebirds (Botton et al. 1994).

Conflicts among the various user groups for horseshoe crabs, as described by Berkson \& Shuster (1999), have stimulated a series of studies to assess population trends in the species. The bait fishery, which was little more than a 'cottage industry' 2 decades ago, exploded due to market forces, with documented landings increasing from just $15900 \mathrm{lb}(7212 \mathrm{~kg})$ in 1970, to about 1 million $\mathrm{lb}(454000 \mathrm{~kg})$ in the early 1990s, and to 6.1 million lb (2.8 million $\mathrm{kg}$ ) in 1997 (ASMFC 1998). Coincident with the expansion of the bait fishery during the last decade, noticeably fewer horseshoe crabs have been counted during the annual spawning census of breeding horseshoe crabs in Delaware Bay (Swan et al. 1997). On some New Jersey beaches, there has been nearly a 10-fold decrease in the density of horseshoe crab eggs in beach sediments, comparing surveys from the 1980s through 1991 with surveys from 1996 to 2000 (Loveland \& Botton 1999). Efforts have been made to develop standardized protocols to sample horseshoe crab eggs and count adult spawners that could be used to detect future trends in the Delaware Bay population (Smith et al. 2002a,b). Finally, ongoing studies have documented declines in the populations of several shorebird species that pass through Delaware Bay (Clark et al. 1993). There is considerable interest in determining the level of egg production that is necessary to maintain a sustainable horseshoe crab fishery, and beyond that, in estimating the level of egg production that would sustain the migratory shorebirds.

A key component to the management of the horseshoe crab fishery has been lacking: to this point, there have been no quantitative studies of survivorship or recruitment in any population. Some years ago, Shuster \& Botton (1985) drew attention to this gap, and they and the Atlantic States Marine Fisheries Commission (ASMFC 1998) both emphasized the impor- tance of understanding larval and juvenile survival to predict recruitment and the effects of fishing pressure on population stability. In fact, relatively little is known about the ecology of young-of-the-year (YOY) Limulus polyphemus. Most horseshoe crab eggs in Delaware Bay are laid on sandy beaches during May and June, and hatch within the beach sand as trilobite (first instar) larvae some 3 to 4 wk later. Trilobites average about $3.3 \mathrm{~mm}$ in carapace width, and except for the absence of the telson, they generally resemble adults (Sekiguchi et al. 1988). A small percentage of trilobites may overwinter (Botton et al. 1992). Trilobites tend to emerge from Delaware Bay beach sediments and enter the plankton following strong onshore winds that cause physical disturbances of the sediment; once in the plankton, they tend to remain close to shore rather than dispersing widely (Botton \& Loveland 2003). After a few hours (Rudloe 1979) or perhaps days of swimming (Shuster 1982) the larvae settle onto the intertidal flats, where they continue to subsist on yolk reserves. Sekiguchi et al. (1988) raised L. polyphemus in captivity, and found that molting took place every $10 \mathrm{~d}$ to $2 \mathrm{wk}$ with the potential to pass through 6 instar stages in their first summer of life. Post-settlement trilobite larvae, and second through fourth instar juveniles may be found on tidal flats, but by late summer or early fall, they leave the flats and migrate into deeper water (Rudloe 1981, Chiu \& Morton 1999). Trilobite larvae subsist on yolk, and subsequent YOY instars appear to feed on sediment organic carbon and meiofauna (Gaines et al. 2002). Carmichael et al. (2003) estimated that about $0.001 \%$ of the horseshoe crab eggs in Pleasant Bay, Massachusetts, survived to the end of their first summer. Older juveniles, up to about $9 \mathrm{~cm}$ prosoma width, return seasonally to the intertidal flats to forage, and are especially active around the daylight low tides (Rudloe 1981).

In this study, we collected quantitative data on the distribution and abundance of YOY horseshoe crabs on the beaches and intertidal sand flats in Delaware Bay, and quantified the survivorship of YOY horseshoe crabs, through the first 4 instars.

\section{MATERIALS AND METHODS}

Study area. Horseshoe crab juveniles were studied in the vicinity of the Rutgers University Cape Shore Laboratory, near the midpoint of the Cape May Peninsula in lower Delaware Bay, New Jersey $\left(39^{\circ} 04.45^{\prime} \mathrm{N}\right.$, $74^{\circ} 54.74^{\prime} \mathrm{W}$ ). A stretch of narrow sandy beach extends from Cape May Point northward for about $21 \mathrm{~km}$, until salt marsh and eroding peat banks predominate north of Reeds Beach. Intertidal flats at the study site consist 
of a series of sand bars parallel to the beach, alternating with shallow, somewhat muddier sloughs (Fig. 1). The maximum tidal amplitude is approximately $2 \mathrm{~m}$ and some 13 sand bars, extending seaward nearly $0.5 \mathrm{~km}$, are exposed during spring low tides. The salinity regime (ca. 18 to $22 \%$ ) is considered to be near optimal for embryonic development and larval hatching (Jegla \& Costlow 1982).

Populations of Instars 1-4 on the intertidal flats. YOY horseshoe crabs, from trilobites through fourth instars, are present on the intertidal flats from about the third week in June until early August. In summer 1998, a preliminary study on the intertidal flats adjacent to the Cape Shore Laboratory was conducted to determine the spatial distribution of juveniles relative to the distance from the shore, position (i.e. sand bar or slough) and sediment characteristics, and to determine the approximate molting schedule of juveniles under field conditions. We sampled for YOY horseshoe crabs along the 'Cape Shore' transect by digging $100 \mathrm{~cm}$ by $25 \mathrm{~cm}$ quadrats to a depth of 2 to $3 \mathrm{~cm}$ using a flat shovel. Below this layer, the sediment is anaerobic and lies beyond the depth to which YOY juveniles will burrow. The long axis of each quadrat was perpendicular to the shoreline. Sediment from the entire $0.25 \mathrm{~m}^{2}$ quadrat was sieved through a $1 \mathrm{~mm}$ screen. We sampled replicate quadrats from the middle of each slough, on the landward edge of each sand bar, in the middle of each bar, and on the seaward edge of each bar. In 1998, sampling for juvenile horseshoe crabs was done on 16 July (first 4 bars and sloughs), 24 July (first 8 bars and sloughs), 29-30 July (first 5 bars and sloughs), 5 August (Bars 1, 4 and 8), 13 August (Bars 1, 3 and 5), and 17 August (Bars 1, 3 and 5).

On the latter 2 dates in 1998, and in all of 1999, we sampled the tidal flats along 3 parallel transects designated as North, Cape Shore, and Highs, located approximately $100 \mathrm{~m}$ apart. These transects were within a generally homogeneous area with a similar beach slope $\left(\sim 6^{\circ}\right)$, beach width $(\sim 15 \mathrm{~m})$, sediment texture, and bar and slough formations on the intertidal flats. Based on the results of the 1998 study, which showed that there were relatively few YOY horseshoe crabs on the outer sand bars, we chose to sample Bars 1,3 , and 5 in 1999. Two replicate quadrats were taken on the landward and seaward edges of each bars at each site. Thus, 36 quadrats were sampled on each date in 1999 (4 samples per bar $\times 3$ bars per transect $\times$ 3 transects). Samples were collected weekly for 8 consecutive weeks, beginning on 22 June and continuing until 13 August 1999, by which time newly emerged trilobites were absent in our plankton surveys (Botton \& Loveland 2003).

Horseshoe crab juveniles retained on the $1 \mathrm{~mm}$ screen were measured and assigned to instar number based on the growth table of Sekiguchi et al. (1988). Contrasts in the number of juveniles among bars and beaches were performed using ANOVA on log-transformed means, followed by post-hoc Tukey Multiple Comparison tests. An alpha level of 0.05 was used throughout.

Densities of horseshoe crab developmental stages on beaches. The densities of horseshoe crab eggs, embryos, and trilobites found in the beach sediments were determined by taking a series of core samples in the mid-intertidal zone adjacent to the 3 tidal flat transects (Cape Shore, North, Highs) during springsummer 1999. A sampling protocol of 40 mid-beach cores was designed to minimize within-beach variance (Smith et al. 2002a). We chose to concentrate our sampling in this section of the beach, based on previous studies that have shown that the highest densities of horseshoe crab eggs and highest percent survival are found there (Botton et al. 1994, Penn \& Brockmann 1994). Sediment samples were taken using $2.5 \mathrm{~cm}$ diameter PVC cores to depth of $20 \mathrm{~cm}$. Forty cores

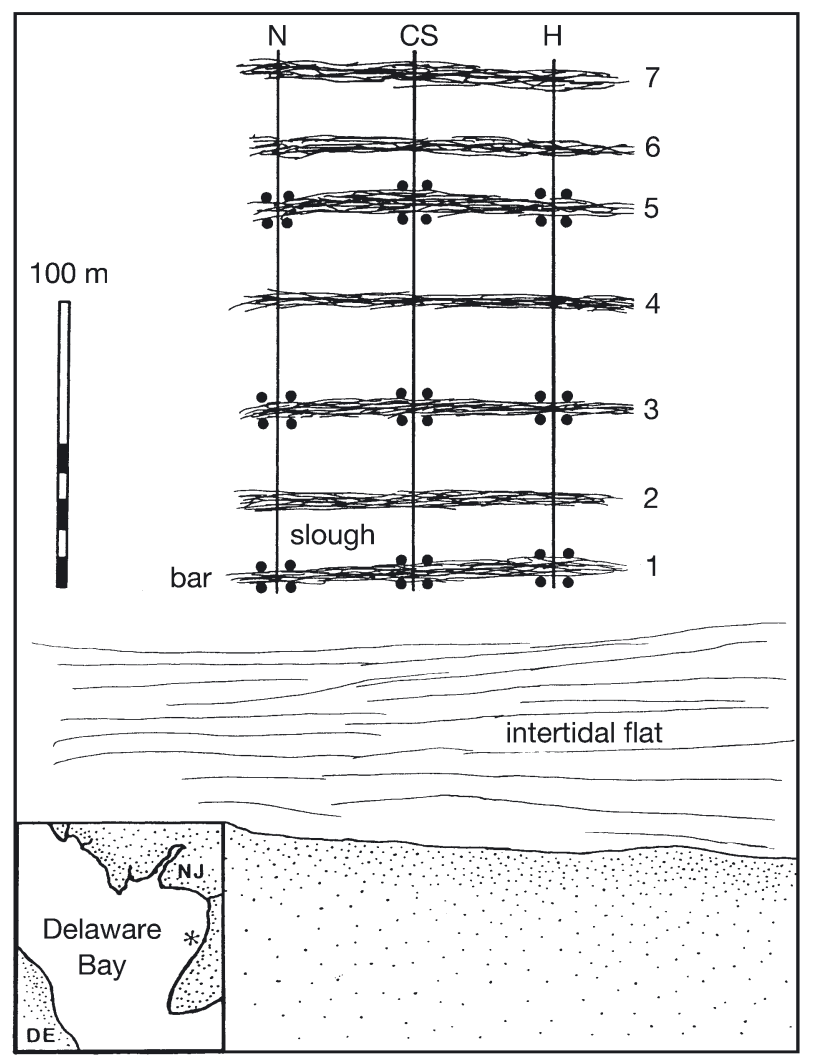

Fig. 1. Schematic diagram of the intertidal sand flats at the study site (* in in Delaware Bay, New Jersey $\left(39^{\circ} 04.45^{\prime} \mathrm{N}\right.$, $\left.74^{\circ} 54.74^{\prime} \mathrm{W}\right)$. The 1999 sampling pattern for juvenile horseshoe crabs is shown; on each date, four $0.5 \mathrm{~m}^{2}$ samples were taken on Bars 1, 3 and 5 on each of 3 transects ( $\mathrm{N}=$ North, $\mathrm{CS}=$ Cape Shore, $\mathrm{H}=$ Highs). Distances between transects not shown to scale 
were taken on the North and Highs transects on 4 dates (25 May, 15 June, 1 July, and 22 July). The Cape Shore transect was sampled only on the latter 2 dates. Cores were taken within a $3 \mathrm{~m}$ wide strip along a $100 \mathrm{~m}$ length of beach; each $3 \mathrm{~m}$ wide strip was centered on the midpoint of the beach foreshore, which is the point halfway between the spring wrack line and the beach break (i.e. beginning of the intertidal flats). The position of each core was determined by randomly selecting 40 locations lengthwise within the $100 \mathrm{~m}$ strip, and then randomly selecting a vertical position along the $3 \mathrm{~m}$ width. Samples were kept in a cold room prior to analysis to retard development and decay of the eggs. Live and dead horseshoe crab developmental stages (eggs, embryos, and trilobite larvae) were enumerated after sieving the sand from each core through a $1 \mathrm{~mm}$ mesh screen.

Sediment analysis. Sediment samples from the upper $2 \mathrm{~cm}$ of the first 8 bars and sloughs of the tidal flats were taken to determine if grain-size distribution and organic carbon content influenced the distribution of YOY horseshoe crabs. Grain-size distribution was obtained by screening the dried sand on a nested sieve series $(4 \mathrm{~mm}, 2 \mathrm{~mm}, 1 \mathrm{~mm}, 500 \mu \mathrm{m}, 250 \mu \mathrm{m}, 125 \mu \mathrm{m}$, and $63 \mu \mathrm{m})$. Statistical measures of central tendency and sorting were calculated following Folk (1974). Organic carbon content was determined following ignition in a muffle furnace at $500^{\circ} \mathrm{C}$ for $5 \mathrm{~h}$.

\section{RESULTS}

\section{Spatial distribution of YOY juveniles (1998)}

Based on YOY surveys taken on the sand bars and sloughs between 16 to 30 July 1998, there were no significant differences in the densities of trilobites, second instars, or third instars when comparing the first bar with the first slough, the second bar with the second slough, or the third bar with the third slough (all contrasts, $\mathrm{p}>0.05$, 2-tailed $t$-tests using log-transformed data). There were more fourth instars in the first slough $(\bar{x}=1.0$ per quadrat) than the first bar $(\bar{X}=0.07$ per quadrat) $\left(t_{(30)}=2.35, \mathrm{p}=0.025\right)$, but the difference is somewhat trivial given the low densities of fourth instars. Accordingly, when we analyzed the 1998 data, we pooled the quadrats from each adjoining bar and slough. Subsequent sampling throughout 1999 was limited to the bars, with the assumption that sloughs had comparable densities.

Only trilobites and second instars were present on 16 July 1998 (Fig. 2A), and there were no significant differences in density among the first 4 sand bars for either trilobites $\left(F_{(3,28)}=2.72, \mathrm{p}=0.06\right)$ or second instars $\left(F_{(3,28)}=1.27, \mathrm{p}=0.30\right)$.

On 24 July 1998, sampling was extended to the first 8 bars, and a significant diminution in juvenile density with distance from shore was evident for trilobites

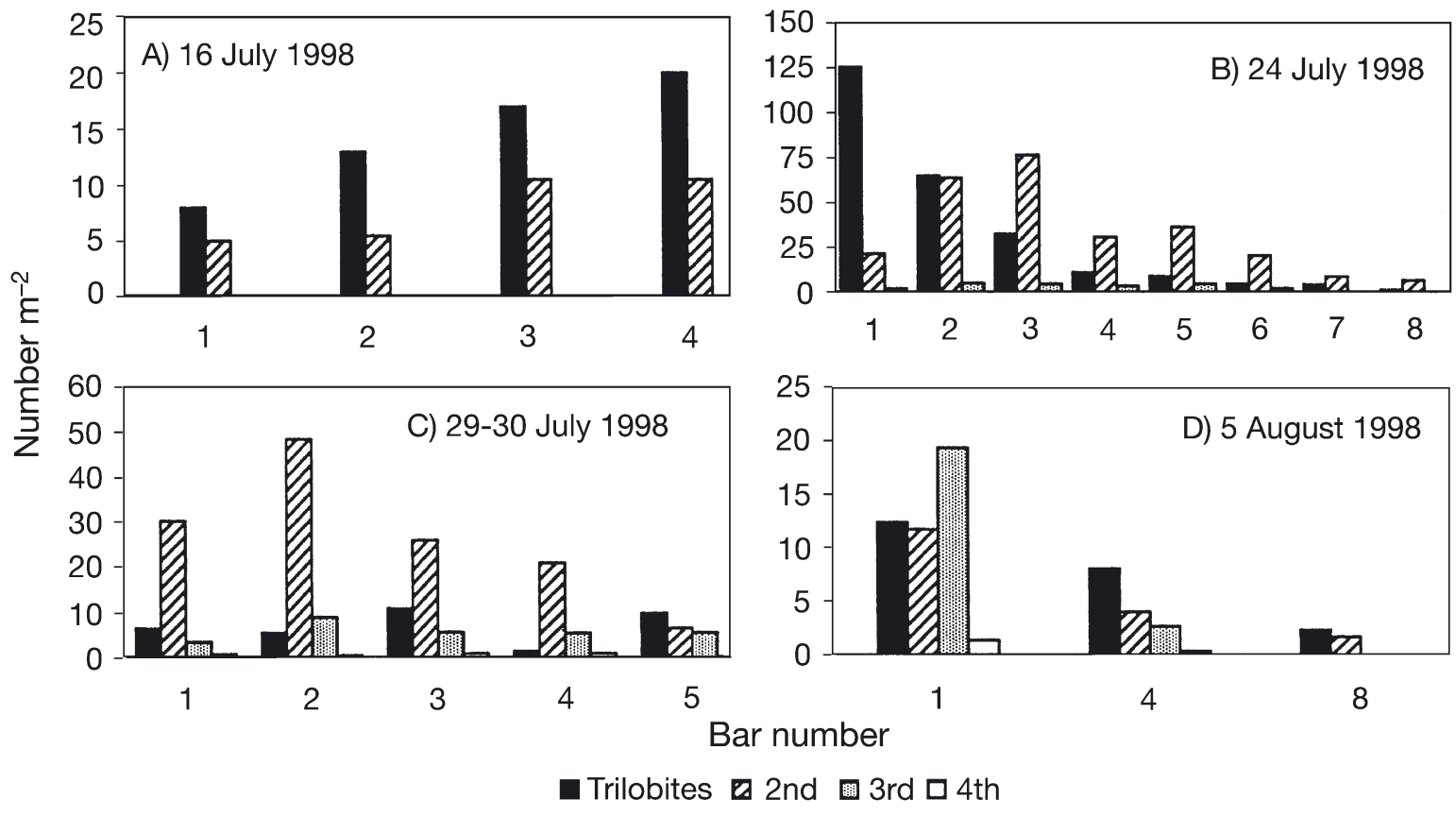

Fig. 2. Limulus polyphemus. Mean density $\left(\mathrm{m}^{-2}\right)$ of YOY horseshoe crabs (trilobites, second instars, third instars, and fourth instars) related to distance from shore (Bar number) on the Delaware Bay, intertidal sand flats in 1998 . (A) 16 July;

(B) 24 July; (C) 29-30 July; (D) 5 August 
Table 1. Sediment characteristics of the first 8 bars and sloughs of the intertidal flats in lower Delaware Bay. 'Landward' and 'Seaward' refer to edges of each sand bar

\begin{tabular}{|c|c|c|c|c|c|c|c|c|c|}
\hline \multirow[t]{2}{*}{ Parameter } & \multirow[t]{2}{*}{ Position } & \multicolumn{8}{|c|}{-Bar number- } \\
\hline & & 1 & 2 & 3 & 4 & 5 & 6 & 7 & 8 \\
\hline \multirow[t]{3}{*}{ Median grain size $(\mu \mathrm{m})$} & Slough & 537 & 437 & 393 & 208 & 174 & 168 & 164 & 164 \\
\hline & Landward & 362 & 352 & 315 & 298 & 317 & 281 & 307 & 169 \\
\hline & Seaward & 650 & 310 & 272 & 260 & 266 & 314 & 238 & - \\
\hline \multirow[t]{3}{*}{$\%$ organic carbon } & Slough & 0.4 & 3.7 & 4.1 & 4.8 & 2.2 & 0.9 & 0.7 & 0.4 \\
\hline & Landward & 0.4 & 0.9 & 0.5 & 0.7 & 0.5 & 0.5 & 0.4 & 0.4 \\
\hline & Seaward & 0.8 & 0.7 & 0.7 & 1.2 & 0.7 & 0.6 & 0.6 & - \\
\hline
\end{tabular}

$\left(F_{(7,56)}=3.94, \mathrm{p}=0.001\right)$ and second instars $\left(F_{(7,56)}=\right.$ 2.51, $\mathrm{p}=0.03$ ) (Fig. 2B). Fewer third instars were found than trilobites or second instars, but there were no significant differences for this stage among bars $\left(F_{(7,56)}=\right.$ 1.87, $\mathrm{p}=0.09$ ).

On 29-30 July 1998, trilobites and second, third, and fourth instars were found on the first 5 sand bars (Fig. 2C). The density of trilobites was significantly different among bars $\left(F_{(4,75)}=5.95, \mathrm{p}<0.001\right)$, but not in a clearly defined onshore-offshore pattern (Bars 3 and 5 were significantly higher than Bar 4, but no other means were significantly different). Second instars generally declined with distance offshore; they were significantly more abundant on Bar 2 than on Bar 5 $\left(F_{(4,75)}=4.17, \mathrm{p}=0.004\right)$, but no other means were significantly different. There were no significant differences among bars in densities of third and fourth instars on this date.

Significant differences among Bars 1, 4, and 8 were found on 5 August 1998 (Fig. 2D). Bar 1 had significantly more trilobites than Bar $8\left(F_{(2,33)}=5.89, \mathrm{p}=\right.$ 0.011). Bar 1 also had significantly more second instars $\left(F_{(2,33)}=10.60, \mathrm{p}<0.001\right)$ and third instars $\left(F_{(2,33)}=24.44, \mathrm{p}<0.001\right)$ compared with both Bars 4 and 8.

The densities of trilobites, second instars, and third instars on 13 August 1998 showed no significant differences with respect to position on the sand bar (landward or seaward edge), bar number $(1,3$, or 5), or transect (North, Cape Shore, Highs) (ANOVA, p > 0.05). On 18 August, there were significantly more trilobites on the Highs Beach transect $\left(F_{(2,33)}=5.91, \mathrm{p}=0.006\right)$ but there were no significant differences among Bars 1,3 , and 5 . We found no second or third instars and only 2 fourth instars on 18 August.

The sediments on the intertidal flats consisted of well-sorted fine to medium sands, with somewhat finer sediments in the sloughs than on the landward or seaward edges of the bars (Table 1). Sediment organic carbon ranged from about 0.4 to $1.2 \%$ on the bars, but was between 2.2 and $4.7 \%$ in Sloughs 2 to 5 .

\section{Seasonal abundance of YOY juveniles (1999)}

The primary objective of the 1999 study was to track the seasonal abundance of Instars 1 to 4 on the nearshore portion of the tidal flats. Based on the 1998 results, we considered that Bars 1, 3, and 5 were representative of this region. On 22 June 1999, only trilobites were encountered on the intertidal flats. Trilobites reached their peak abundance, $33.4 \mathrm{~m}^{-2}$, on 7 July and continued to be relatively abundant (ca. $10 \mathrm{~m}^{-2}$ ) through the end of July before decreasing steeply in August (Table 2). Second instars were first encountered on 29 June, and they reached their maximum density of $9.4 \mathrm{~m}^{-2}$ on 14 July, i.e. one week after the maximum in trilobite density. Third instars were first collected on 7 July, and reached a maximum density of $0.7 \mathrm{~m}^{-2}$ on 21 July. They were absent from the collections in August. Finally, fourth instar juveniles were only found on 28 July, at a density of $0.1 \mathrm{~m}^{-2}$. The temporal occurrence of the maxima for each stage suggests that the average intermolt duration was approximately $1 \mathrm{wk}$.

There was a weak tendency of YOY juveniles in 1999 to be more abundant on Bars 1 and 3 than on

Table 2. Limulus polyphemus. Densities (ind. $\mathrm{m}^{-2}$ ) of YOY horseshoe crabs on the lower Delaware Bay, tidal flats in 1999 ( $\mathrm{n}=36$ samples per date). Total ind.: sum of all crabs that inhabited a square meter of bottom during the study

\begin{tabular}{|lcccc|}
\hline \multirow{2}{*}{ Date } & \multicolumn{4}{c|}{ Instars } \\
\cline { 2 - 5 } & 1st & 2nd & 3rd & 4th \\
\hline 22 June & 5.4 & 0.0 & 0.0 & 0.0 \\
29 June & 18.1 & 1.4 & 0.0 & 0.0 \\
7 July & 33.4 & 5.0 & 0.1 & 0.0 \\
14 July & 11.6 & 9.4 & 0.4 & 0.0 \\
21 July & 6.0 & 2.2 & 0.7 & 0.0 \\
28 July & 9.7 & 2.7 & 0.6 & 0.1 \\
5 August & 0.2 & 0.3 & 0.0 & 0.0 \\
13 August & 1.1 & 0.0 & 0.0 & 0.0 \\
Total ind. & & & & \\
22 June-13 August & 85.6 & 21.1 & 1.8 & 0.1 \\
22 June-28 July & 84.2 & 20.8 & 1.8 & 0.1 \\
\hline
\end{tabular}



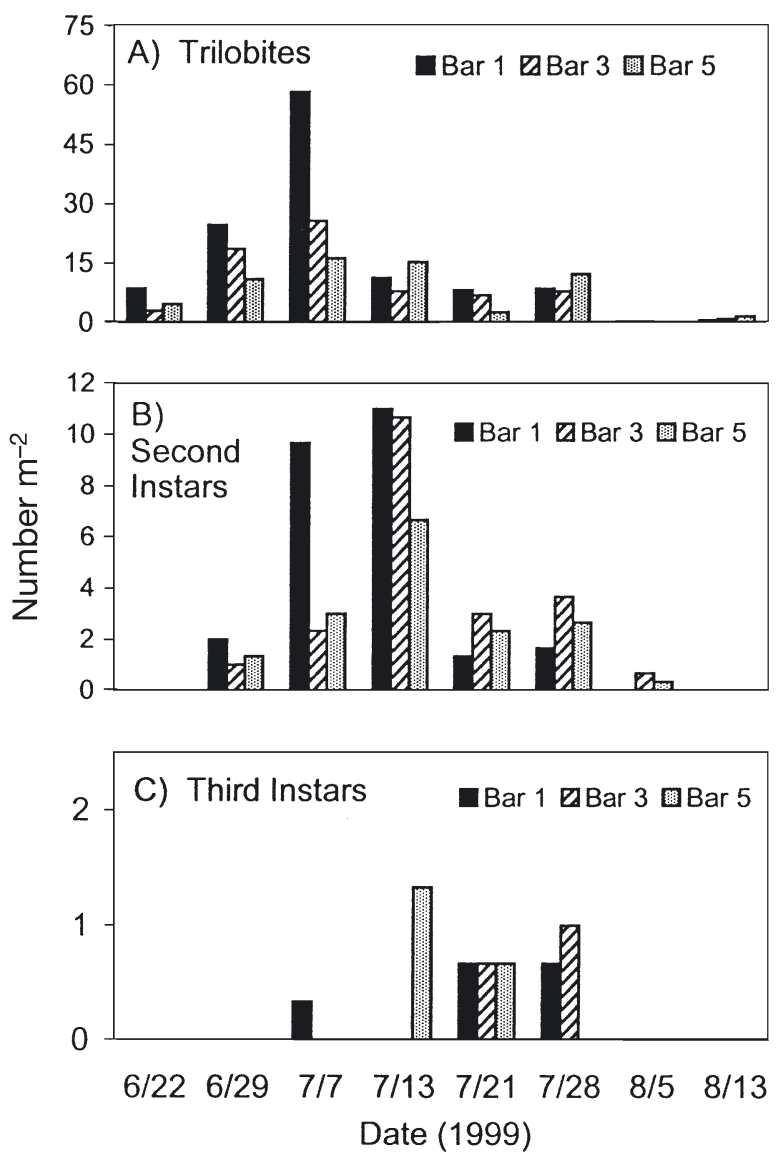

Fig. 3. Limulus polyphemus. Mean density $\left(\mathrm{m}^{-2}\right)$ of $(\mathrm{A})$ trilobites, (B) second instars, and (C) third instars on Bars 1, 3, and 5 of the tidal flats between 22 June and 13 August 1999

Bar 5. Differences among bars were statistically significant for trilobites (Fig. 3A) on only 29 June $\left(F_{(2,33)}=\right.$ 4.80, $\mathrm{p}=0.015$; Bar $1>$ Bar 5) and 7 July $\left(F_{(2,33)}=10.43\right.$, $\mathrm{p}<0.001$; Bar $1>$ Bar 5). For second instars (Fig. 3B) there were significant differences among bars (Bar $1>$ Bars 3 and 5$)$ on only 7 July $\left(F_{(2,33)}=5.89, \mathrm{p}=0.007\right)$. Third instars (Fig. 3C) were quite scarce, and the one statistically significant difference among bars on 13 July $\left(F_{(2,33)}=5.50, \mathrm{p}=0.009\right)$ may have no ecological meaning given the low densities at all locations. Differences among transects (North, Cape Shore, Highs) were also small (4 instances among 32 comparisons where $\mathrm{p}<0.05$ ) and did not show any consistent patterns.

\section{Survival of epibenthic YOY}

Given that differences among the 3 sand bars and 3 transects in 1999 were relatively small, we averaged all 36 samples on each date to derive an approximation
Table 3. Limulus polyphemus. Percentages of post-settlement stages of crabs remaining on Delaware Bay tidal flats, based on the total densities of each stage sampled between 22 June to 13 August 1999 (see Table 2)

\begin{tabular}{|c|c|c|c|c|}
\hline & 1st instar & 2nd instar & 3rd instar & 4th instar \\
\hline 1st instar & & 24.7 & 2.1 & 0.1 \\
\hline 2nd instar & & & 8.4 & 0.5 \\
\hline 3rd instar & & & & 6.2 \\
\hline
\end{tabular}

of the overall reduction in numbers from one epibenthic juvenile stage to the next. Since molting took place about weekly (Table 2), we assumed that the individuals of a particular stage from one week either molted, died, or otherwise left the system by the next week. The densities of each instar on each sampling date were summed to estimate the total number of that stage that resided on the intertidal flats over the $8 \mathrm{wk}$ period. When the number in each instar is divided by the number in the subsequent instar, these data suggest that an epibenthic trilobite larva has a $24.7 \%$ chance of persisting to the second instar stage, a $2.08 \%$ chance of persisting to the third instar stage, and only a $0.13 \%$ probability of survival to the fourth instar stage (Table 3).

An alternative approach to estimating YOY losses is to track the fate of presumed cohorts of individuals (Table 4). For example, if we presume that the majority of the 18.1 trilobites $\mathrm{m}^{-2}$ on 29 June molted in the following week and thus became the 5.0 second instars $\mathrm{m}^{-2}$ on 7 July, this would suggest that this particular cohort had a $27.6 \%$ survival to the second instar. Similarly, from these 5.0 second instars $\mathrm{m}^{-2}$, there were only 0.44 third instars $\mathrm{m}^{-2} 1 \mathrm{wk}$ later $(8.9 \%)$, projecting that $2.45 \%$ of the 29 June trilobite cohort survived to the third instar stage. The loss estimates, obtained by looking at presumed cohorts in this manner, generally gave predictions that were similar to those derived by pooling the entire season's data, as in Table 3. The most striking disparity among trilobite cohorts was the very low survival of the 28 July cohort, which had only

Table 4. Limulus polyphemus. Percentages of post-settlement cohorts of trilobite larvae remaining as instars on the Delaware Bay tidal flats in 1999

\begin{tabular}{|lcc|}
\hline Trilobite cohort & 2nd instar & 3rd instar \\
\hline 29 June & 27.6 & 2.5 \\
7 July & 28.2 & 2.0 \\
14 July & 19.2 & 4.8 \\
21 July & 44.4 & 0.0 \\
28 July & 3.4 & 0.0 \\
Mean of 5 cohorts & 24.6 & 1.9 \\
\hline
\end{tabular}


a $3.45 \%$ survival to the second instar stage. Survival of second instar cohorts into third instars ranged between 7 and $9 \%$, with the exception of the 21 July cohort, which was $25 \%$. Survival of trilobite cohorts into third instars ranged from 2 to $4.8 \%$.

\section{Survival of trilobite larvae on beaches to epibenthic instars}

To make comparisons between the densities of trilobites within the beach sediments with the epibenthic stages on the intertidal flats, several simplifying assumptions were made. First, we took the conservative approach that the density of trilobites within the $3 \mathrm{~m}$ wide sampling area within the mid-beach represented the production of the entire $15 \mathrm{~m}$ width of the beach. Second, based on the 1998 transect studies, we assumed that the density of YOY on the sand bars in 1999 was comparable in the adjacent sloughs, and we further assumed that the average YOY densities on the bars could be projected from the start of the first bar through the end of the fifth bar, a distance of approximately $200 \mathrm{~m}$. We extrapolated the density of YOY crabs from the sixth slough through eighth bar by assuming that the outer bars contained 10 to $20 \%$ of the density on the inner 5 bars (derived from the transect surveys of 24 July and 5 August 1998). Lastly, we assumed that there were negligible numbers of YOY crabs seaward of the eighth bar. To deduce losses from trilobite larvae in beach sediments to epibenthic trilobites on the tidal flats, we are therefore comparing the total number within a $1 \mathrm{~m}$ wide band that extends $3 \mathrm{~m}$ within the mid-beach with a $1 \mathrm{~m}$ wide band extending $300 \mathrm{~m}$ out to the eighth sand bar on the flats.

During the entire 1999 season, horseshoe crabs deposited about 1.5 million eggs within a $1 \mathrm{~m}$ by $3 \mathrm{~m}$ band in the mid-beach area (Table 5). We estimated that about half of the eggs (761 000) successfully developed into live trilobites by the end of July, at which time only $0.85 \%$ of the eggs and embryos remaining in the beach sediments were alive. In comparison, during the $8 \mathrm{wk}$ between 22 June and 13 August, we estimated between 17967 and 19250 trilobites in the $1 \mathrm{~m}$ band extending out $300 \mathrm{~m}$ onto the flats (Table 5). Thus, about 2.4 to $2.5 \%$ of the live trilobites on the beaches are estimated to have survived to become epibenthic trilobites on the intertidal flats during 1999. Similar estimates were obtained by examining the survival of presumptive cohorts of beach trilobites into benthic trilobites (range 1.2 to $3.2 \%$ ). Between 0.58 and $0.62 \%$ of the beach trilobites survived to become second instars, about $0.05 \%$ of the beach trilobites survived to become third instars, and only about $0.003 \%$ of them survived to become fourth instars. In other words, we estimate that about 3 trilobites per 100000 remained as fourth instars on the tidal flats in their first summer.

Table 5. Limulus polyphemus. Survival of live horseshoe crab eggs and trilobites on the beach through the fourth instar stage on tidal flats in 1999. Contrasts are between the total number of trilobites in a $1 \mathrm{~m}$ by $3 \mathrm{~m}$ band of the mid-beach and the total number of juveniles residing within in a $1 \mathrm{~m}$ band across the first 8 sand bars of the flats $(300 \mathrm{~m})$. Model A assumes Bars 6 to 8 have $10 \%$ of the juvenile abundance as the inner bars; Model B assumes Bars 6 to 8 have $20 \%$ of the juvenile abundance as the inner bars

\begin{tabular}{|c|c|c|c|c|c|c|c|c|c|c|}
\hline \multirow[t]{3}{*}{ Date } & \multirow{3}{*}{$\begin{array}{c}\text { Mid-beach } \\
\text { live } \\
\text { eggs }\end{array}$} & \multirow{3}{*}{$\begin{array}{c}\text { Mid-beach } \\
\text { live } \\
\text { trilobites }\end{array}$} & \multicolumn{8}{|c|}{ Densities of juveniles on the tidal flats ( $1 \mathrm{~m}$ band out to Bar 8 ) } \\
\hline & & & & -Mode & $\mathrm{A}$ & - & & - Model & & \\
\hline & & & Trilobites & $\begin{array}{l}\text { 2nd } \\
\text { instar }\end{array}$ & $\begin{array}{c}\text { 3rd } \\
\text { instar }\end{array}$ & $\begin{array}{c}\text { 4th } \\
\text { instar }\end{array}$ & Trilobites & $\begin{array}{l}\text { 2nd } \\
\text { instar }\end{array}$ & $\begin{array}{c}\text { 3rd } \\
\text { instar }\end{array}$ & $\begin{array}{c}\text { 4th } \\
\text { instar }\end{array}$ \\
\hline 25 May & 1138907 & 0 & & & & & & & & \\
\hline 15 June & 349281 & 213081 & & & & & & & & \\
\hline 22 June & & & 1143 & 0 & 0 & 0 & 1225 & 0 & 0 & 0 \\
\hline 29 June & & & 3803 & 303 & 0 & 0 & 4075 & 325 & 0 & 0 \\
\hline 1 July & 34688 & 360500 & & & & & & & & \\
\hline 7 July & & & 7023 & 1050 & 23 & 0 & 7525 & 1125 & 25 & 0 \\
\hline 13 July & & & 2427 & 1983 & 93 & 0 & 2600 & 2125 & 100 & 0 \\
\hline 21 July & & & 1260 & 467 & 140 & 0 & 1350 & 500 & 150 & 0 \\
\hline 22 July & 867 & 187167 & & & & & & & & \\
\hline 28 July & & & 2030 & 560 & 117 & 23 & 2175 & 600 & 125 & 25 \\
\hline 5 August & & & 47 & 70 & 0 & 0 & 50 & 75 & 0 & 0 \\
\hline 13 August & & & 233 & 0 & 0 & 0 & 250 & 0 & 0 & 0 \\
\hline Grand total & 1523743 & 760748 & 17967 & 4433 & 373 & 23 & 19250 & 4750 & 400 & 25 \\
\hline \multicolumn{3}{|c|}{ Survival (\%) beach trilobites to: } & 2.36 & 0.58 & 0.05 & 0.003 & 2.53 & 0.62 & 0.05 & 0.003 \\
\hline \multicolumn{3}{|c|}{ Survival (\%), 15 June, beach to benthic trilobites: } & 2.32 & & & & 2.49 & & & \\
\hline \multicolumn{3}{|c|}{ Survival (\%), 1 July, beach to benthic trilobites: } & 2.97 & & & & 3.18 & & & \\
\hline \multicolumn{3}{|c|}{ Survival (\%), 22 July, beach to benthic trilobites: } & 1.23 & & & & 1.32 & & & \\
\hline
\end{tabular}




\section{DISCUSSION}

The early survivorship of YOY horseshoe crabs follows a Type III curve typical of most marine invertebrates (Rumrill 1990), with a reduction of about $10^{-5}$ from the larval cohort on the beaches to the surviving fourth instar juveniles in August. Losses are steepest in the life-history transition from trilobites on the beach to trilobites on the intertidal flats, i.e. during the brief planktonic phase or shortly after settlement to the benthos. We have inferred that approximately $97.5 \%$ of the individuals were lost during this transition (Table 5). Once settlement occurred on the flats, an estimated $25 \%$ of the epibenthic trilobites remained to become second instars (Table 3). However, only about $2.1 \%$ of the epibenthic trilobites remained to become third instars, and just $0.13 \%$ of them became fourth instars. Combining the estimates from both the beach and flats, a cohort of 1 million trilobites on the beach would be reduced to about 33 fourth instars at the end of their first summer. To a first approximation, there is a log-fold decrease in density with each molt from the second through the fourth instar. It is conceivable that the densities of third and fourth instars have been underestimated, particularly as the season progressed, since it is known that the older instars tend to move progressively seaward and eventually become subtidal (Rudloe 1981). This migration appears to have taken place between 28 July and 5 August 1999, when the densities of all instars declined (Fig. 3). However, exclusion of the 2 August sampling dates had little effect upon the population estimates or the loss rates derived from these totals (Table 2).

Since we estimated survival by comparing the densities of successive instars, it could be argued that migration out of the system could be confounded with mortality. In this habitat, migration could potentially be occurring as crabs move offshore of the sampled portion of the intertidal flats. For example, if trilobites settled subtidally, we may have underestimated their density on the intertidal flats. However, we believe this is unlikely for 2 reasons. First, plankton tows taken throughout the period of this study showed that trilobites were highly aggregated close to the shoreline (Botton \& Loveland 2003), with very few collected in the vicinity of the fifth sand bar, which is approximately $200 \mathrm{~m}$ offshore. Secondly, since more second instar juveniles were found on the inner bars than on the outer bars (Fig. 2), a hypothesis of offshore trilobite settlement would also require a return migration of considerable distance. We also do not think it is likely that large numbers of second, third, or fourth instar juveniles were migrating offshore of the fifth sand bar before August since we collected very few individuals beyond that bar in 1998 (Fig. 2). Furthermore, the behavior of the juveniles make it unlikely that they would quickly emigrate from the inshore flats during the summer. When they are immersed, they spend most of their time burrowed in the sediment, and when they are exposed, they crawl about slowly, making circuitous trails on sand bars (Rudloe 1981). Nonetheless, the most cautious interpretation of our data is that they represent loss (mortality + emigration) estimates, which define the upper limit to mortality. Should juveniles select and migrate between habitats as a function of size (Pile et al. 1996, Etherington \& Eggleston 2000, Moksnes 2002), successive samples from the habitat where settlement occurred would tend to overestimate mortality. However, if juvenile movements between habitats are minimal, it is more reasonable to relate losses between successive size-classes to mortality (e.g. Watson et al. 2002).

Our estimate of first year survival in Limulus polyphemus is consistent with Carmichael et al. (2003), who inferred a $0.001 \%$ survival from the eggs to the end of the first summer in the Pleasant Bay, Massachusetts, population. In contrast to our study, Carmichael et al. (2003) did not directly enumerate egg density; instead they estimated it from the number of mature females in the population. They counted subtidal adult crabs, and the female reproductive effort was assumed to be spread out equally across all suitable habitats within the estuary, rather than in particular concentrations. They sampled for small juvenile horseshoe crabs on intertidal flats, where the crabs were hand-picked from sediments; thus, as in our study, mortality could have been confounded with emigration to the subtidal. Despite some of the methodological differences between Carmichael et al.'s (2003) study and ours, the similar estimates of YOY survival suggests that similar demographic processes are at work in the Delaware Bay and Pleasant Bay horseshoe crab populations.

The specific causes of YOY horseshoe crab mortality in Delaware Bay have not been quantified, but could potentially involve factors such as adverse environmental conditions, or predation in the plankton or after settlement. The first factor seems unlikely, as trilobite larvae are well known for their abilities to tolerate high temperatures under varying salinities (Jegla \& Costlow 1982) and they can survive levels of pollution far in excess of what is found in lower Delaware Bay (Itow et al. 1998, Botton 2000). Potential predators of planktonic trilobites include small fishes (Shuster 1982) and Laughing Gulls (author's pers. obs.). Although they are exposed around the low tides, juvenile horseshoe crabs have minimal risk from shorebird predation, because the large shorebird population that migrates through Delaware Bay departs by early June (Clark et al. 1993), several weeks before the trilobite larvae emerge from beach sediments. Based on preliminary laboratory 
feeding experiments, potential predators of epibenthic trilobites and the later instar stages include hermit crabs Pagurus longicarpus, xanthid crabs, and juvenile blue crabs Callinectes sapidus (A. Tiwari unpubl. data).

Newly settled horseshoe crab juveniles were equally abundant on sand bars and muddy sloughs, but were generally more abundant near the beach (Fig. 2). Although the distribution pattern across the tidal flats may primarily be related to distance from shore, the inshore sediments tended to have a somewhat higher organic carbon content, especially in the sloughs (Table 1), which may reflect the presence of detritus, meiofauna, or other potential sources of nutrition (Gaines et al. 2002). Juvenile horseshoe crabs do not appear to be analogous to many other marine arthropods, such as American lobsters, spiny lobsters, rock crabs, king crabs, and blue crabs, which have been shown to have much higher juvenile survival in the presence of structures afforded by cobble, rock, and submerged aquatic vegetation (Heck \& Thoman 1984, Cobb et al. 1997, Palma et al. 1998, Loher \& Armstrong 2000). Structurally complex habitats provide refugia from predation, but in the absence of such structure, shallow water habitats may afford small epibenthic animals a relative degree of protection from predatory fish and crabs, in comparison to deeper water (Ruiz et al. 1993). The intertidal flats studied in this portion of Delaware Bay are relatively featureless, except for small patches of oyster Crassostrea virginica reefs that have developed on discarded shells. Juvenile horseshoe crabs are capable of burrowing, and presumably foraging, on a variety of sediment types (Meury \& Gibson 1990).

There is insufficient information to determine if the processes that determine the survivorship of YOY horseshoe crabs are density-dependent or densityindependent. We have estimated that to get 1 surviving fourth instar per meter band on the flats in 1999, it would have required a density of approximately 100000 trilobites per meter band in the mid-beach (i.e. $33000 \mathrm{~m}^{-2}$ ). Clearly, one cannot have more adults from a particular year-class than there are fourth instars. We do not know the survivorship from fourth instars through adults, but an appreciable length of time is required. Sixteenth-instar males, 8 yr old, molt into adults in their ninth year, whereas 17 th-instar females molt into adults in their tenth year (Sekiguchi et al. 1988). Recruitment in marine animals is highly variable, and linkages between the abundance of spawning adults, larvae, and eventual recruits are not easily predictable (Fogarty et al. 1991, Grosberg \& Levitan 1992). While the presumption of a density-independent relationship between spawning stock and recruitment may be overly simplistic (Fogarty et al. 1991), a meta-analysis of empirical data from 364 marine fisheries did support the hypothesis that there is a positive relationship between spawner abundance and recruitment (Myers \& Barrowman 1996). It will require a long-term study to determine if adult recruitment in horseshoe crabs is linked to the size of juvenile yearclasses. However, if egg densities on some beaches were as much as 10-fold higher in the 1980s than they were in 1999 (Loveland \& Botton 1999), we suggest that there may have been correspondingly higher YOY densities on the intertidal flats, assuming that the causes of YOY mortality are not strongly densitydependent. Given this, and the approximate 9 to $10 \mathrm{yr}$ maturation period (Sekiguchi et al. 1988), it is quite probable that the present adult population size in Delaware Bay is a consequence of the large spawning population in the late 1980s and early 1990s (Swan et al. 1997, Loveland \& Botton 1999). In spite of more stringent regulations on the horseshoe crab fishery in New Jersey, including the elimination of hand collections within 1000 feet $(305 \mathrm{~m})$ of a beach, limitation of the hand collections to $2 \mathrm{~d} \mathrm{wk}^{-1}$, and limited entry into the fishery, these landings have remained steady, while those landed by trawlers have increased (P. Himchak, New Jersey Department of Environmental Protection, pers. comm.). Should there be a further drop in the numbers of adult spawners, egg densities, and hence the densities of all subsequent stages, would be expected to decline as well.

Acknowledgements. We are grateful to our assistants, C. Creamer, J. Jacobsen, E. Stover, and H. Uhden, who helped us with the field sampling. This publication is a result of work funded by the NOAA Office of Sea Grant and Extramural Programs, US Department of Commerce, under grant R/F-9719. The US Government is authorized to produce and distribute reprints for governmental purpose notwithstanding any copyright notation that may appear hereon. This is publication NJSG-03-523.

\section{LITERATURE CITED}

ASMFC (Atlantic States Marine Fisheries Commission) (1998) Interstate fishery management plan for horseshoe crab. Fish Manag Rep 32:1-39

Berkson J, Shuster CN Jr (1999) The horseshoe crab: the battle for a true multiple-use resource. Fisheries (Bethesda) 24:6-12

Botton ML (2000) Toxicity of cadmium and mercury to horseshoe crab (Limulus polyphemus) embryos and larvae. Bull Environ Contamin Toxicol 64:137-143

Botton ML, Loveland RE (2003) Abundance and dispersal potential of horeshoe crab (Limulus polyphemus) larvae in the Delaware estuary. Estuaries 26:1472-1479

Botton ML, Ropes JW (1987a) Populations of horseshoe crabs on the northwestern Atlantic continental shelf. Fish Bull US 85:805-812

Botton ML, Ropes JW (1987b) The horseshoe crab, Limulus polyphemus, fishery and resource in the United States. Mar Fish Rev 49:57-61

Botton ML, Loveland RE, Jacobsen TR (1992) Overwintering by trilobite larvae of the horseshoe crab Limulus polyphe- 
mus on a sandy beach of Delaware Bay (New Jersey, USA). Mar Ecol Prog Ser 88:289-292

Botton ML, Loveland RE, Jacobsen TR (1994) Site selection by migratory shorebirds in Delaware Bay, and its relationship to beach characteristics and abundance of horseshoe crab (Limulus polyphemus) eggs. Auk 111:605-616

Carmichael RH, Rutecki D, Valiela I (2003) Abundance and population structure of the Atlantic horseshoe crab Limulus polyphemus in Pleasant Bay, Cape Cod. Mar Ecol Prog Ser 246:225-239

Castro G, Myers JP (1993) Shorebird predation on eggs of horseshoe crabs during spring stopover on Delaware Bay. Auk 110:927-930

Chiu HMC, Morton B (1999) The biology, distribution, and status of horseshoe crabs, Tachypleus tridentatus and Carcinoscorpius rotundicauda (Arthropoda: Chelicerata) in Hong Kong: recommendations for conservation and management. Final Report to China Light and Power Company Limited. Swire Institute of Marine Science, University of Hong Kong, Hong Kong

Clark KE, Niles LJ, Burger J (1993) Abundance and distribution of migrant shorebirds in Delaware Bay. Condor 95: 694-705

Cobb JS, Booth JD, Clancy M (1997) Recruitment strategies in lobsters and crabs: a comparison. Mar Freshw Res 48: 797-806

Etherington LL, Eggleston DB (2000) Large-scale blue crab recruitment: linking postlarval transport, post-settlement planktonic dispersal, and multiple nursery habitats. Mar Ecol Prog Ser 204:179-198

Fogarty MJ, Sissenwine MP, Cohen EB (1991) Recruitment variability and the dynamics of exploited marine populations. Trends Ecol Evol 6:241-246

Folk RL (1974) Petrology of sedimentary rocks. Hemphill, Austin, TX

Gaines EF, Carmichael RH, Grady SP, Valiela A (2002) Stable isotopic evidence for changing nutritional sources of juvenile horseshoe crabs. Biol Bull (Woods Hole) 203:228-230

Grosberg RK, Levitan DR (1992) For adults only? Supply-side ecology and the history of larval biology. Trends Ecol Evol $7: 130-133$

Heck KL Jr, Thoman TA (1984) The nursery role of seagrass meadows in the upper and lower reaches of the Chesapeake Bay. Estuaries 7:70-92

Itow T, Loveland RE, Botton ML (1998) Developmental abnormalities in horseshoe crab embryos caused by heavy metals. Arch Environ Contamin Toxicol 35:33-40

Jegla TC, Costlow JD (1982) Temperature and salinity effects on development and early posthatch stages of Limulus. In: Bonaventura J, Bonaventura C, Tesh S (eds) Physiology and biology of horseshoe crabs. Alan R Liss, New York, p 103-113

Loher T, Armstrong DA (2000) Effects of habitat complexity and relative larval supply on the establishment of early benthic phase red king crab (Paralithodes camtschaticus Tilesius, 1815) populations in Auke Bay, Alaska. J Exp Mar Biol Ecol 245:83-109

Loveland RE, Botton ML (1999) Executive summary of horseshoe crab egg density studies on Delaware Bay, New Jersey from 1985 thru 1999. Endangered and non-game species program, Department of Environmental Protection, State of New Jersey, Trenton, NJ

Manion MM, West RA, Unsworth RE (2000) Economic assessment of the Atlantic coast horseshoe crab fishery. Report to the US Fish and Wildlife Service, Division of Economics, Arlington, VA

Meury TW, Gibson DG III (1990) Force generation in juvenile
Limulus polyphemus: effects on mobility in the intertidal environment. Bull Mar Sci 47:536-545

Moksnes PO (2002) The relative importance of habitatspecific settlement, predation and juvenile dispersal for distribution and abundance of young juvenile shore crabs Carcinus maenas L. J Exp Mar Biol Ecol 271:41-73

Myers RA, Barrowman NJ (1996) Is fish recruitment related to spawner abundance? Fish Bull US 94:707-724

Novitsky TJ (1984) Discovery to commercialization: the blood of the horseshoe crab. Oceanus 27:13-18

Palma AT, Wahle RT, Steneck RS (1998) Different early postsettlement strategies between American lobsters Homarus americanus and rock crabs Cancer irroratus in the Gulf of Maine. Mar Ecol Prog Ser 162:215-225

Penn D, Brockmann HJ (1994) Nest-site selection in the horseshoe crab, Limulus polyphemus. Biol Bull (Woods Hole) 187:373-384

Pile AJ, Lipcius RN, van Montfrans J, Orth RJ (1996) Densitydependent settler-recruit-juvenile relationships in blue crabs. Ecol Monogr 66:277-300

Rudloe A (1979) Locomotor and light responses of larvae of the horseshoe crab, Limulus polyphemus (L.). Biol Bull (Woods Hole) 157:495-505

Rudloe A (1981) Aspects of the biology of juvenile horseshoe crabs, Limulus polyphemus. Bull Mar Sci 31:125-133

Ruiz GM, Hines AH, Posey MH (1993) Shallow water as refuge habitat for fish and crustaceans in non-vegetated estuaries: an example from Chesapeake Bay. Mar Ecol Prog Ser 99:1-16

Rumrill SS (1990) Natural mortality of marine invertebrate larvae. Ophelia 32:163-198

Sekiguchi K, Seshimo H, Sugita H (1988) Post-embryonic development of the horseshoe crab. Biol Bull (Woods Hole) 174:337-345

Shuster CN Jr (1979) Distribution of the American horseshoe ' $\mathrm{Crab}^{\prime}$, Limulus polyphemus (L.). In: Cohen E (ed) Biomedical applications of the horseshoe crab (Limulidae). Alan R Liss, New York, p 3-26

Shuster CN Jr (1982) A pictorial review of the natural history and ecology of the horseshoe crab Limulus polyphemus, with reference to other Limulidae. In: Bonaventura J, Bonaventura C, Tesh S (eds) Physiology and biology of horseshoe crabs. Alan R Liss, New York, p 1-52

Shuster CN Jr, Botton ML (1985) A contribution to the population biology of horseshoe crabs, Limulus polyphemus (L.), in Delaware Bay. Estuaries 8:363-372

Smith DR, Pooler PS, Loveland RE, Botton ML, Michels SF, Weber RG, Carter DB (2002a) Horseshoe crab (Limulus polyphemus) reproductive activity on Delaware Bay beaches: interactions with beach characteristics. J Coastal Res 18:730-740

Smith DR, Pooler PS, Swan BL, Michels SF, Hall WR, Himchak PJ, Millard MJ (2002b) Spatial and temporal distribution of horseshoe crab (Limulus polyphemus) spawning in Delaware Bay: implications for monitoring. Estuaries 25: 115-125

Swan BL, Hall WR, Shuster CN Jr (1997) Annual survey of horseshoe crab spawning activity along the shores of Delaware Bay: 1990-1995 summary. In: Farrell J, Martin C (eds) Status of the resource: proceedings of the horseshoe crab forum. Publication DEL-SG-05-97, University of Delaware Sea Grant College Program, Lewes, DE, p 35-37

Tsipoura N, Burger J (1999) Shorebird diet during spring migration stopover on Delaware Bay. Condor 101:635-644

Watson M, Munro JL, Gell FR (2002) Settlement, movement and early juvenile mortality of the yellowtail snapper Ocyurus chrysurus. Mar Ecol Prog Ser 237:247-256 